\title{
MELANOTIC SCHWANNOMA OF THE LUMBAR SPINE: A CASE REPORT AND LITERATURE REVIEW
}

\author{
SCHWANNOMA MELANOCÍTICO DA COLUNA LOMBAR: RELATO DE CASO \\ E REVISÃO DE LITERATURA
}

\author{
SCHWANNOMA MELANÓTICO DE LA COLUMNA LUMBAR: REPORTE DE UN CASO \\ Y REVISIÓN DE LA LITERATURA
}

João Bernardo Sancio Rocha Rodrigues', Nathália Ambrozim Santos Saleme ${ }^{1}$, Charbel Jacob Junior², José lucas Batista Junior², igor Machado Cardoso², Luciene Lage da Motta², Rodrigo dos Santos Lugäo², Rodrigo Rezende²

\begin{abstract}
Schwannomas are benign tumors, usually solitary, encapsulated, slow-growing, which have their origin in differentiated neoplastic Schwann cells with extramedullary intradural usual development related to nerve roots. The melanotic schwannoma is a variant of these tumors whose location in almost one third of cases is on the posterior spinal nerve root, with a nonspecific clinical presentation. Magnetic resonance imaging is the most widely used test for the diagnosis, revealing hyperintense T1-weighted sequences and hypointense T2-weighted sequences. Diagnostic confirmation is obtained by histological and immunohistochemical studies, in which there is intense cytoplasmatic pigmentation. There are two distinct types of melanotic schwannomas: sporadic and psammomatous, the latter related to the called Carney complex, a form of multiple endocrine neoplasm with familiar character. In literature we found few cases of these neoplasms, the largest series consisting of five cases. The objective of this study is to report a rare case of melanotic schwannoma of the lumbar spine of the sporadic type of extramedullary location. We also present a brief review of the literature containing the main characteristics of the tumor, including its different forms, differential diagnoses, data from histological and immunohistochemical studies as well as the currently recommended approach in order to contribute to a better understanding of this neoplasm.
\end{abstract}

Keywords: Spine; Spinal neoplasms; Schwann Cells; Manipulation, spinal.

\begin{abstract}
RESUMO
Os schwannomas são tumores benignos, geralmente solitários, encapsulados e de crescimento lento, que têm sua origem nas células de Schwann neoplásicas diferenciadas, com desenvolvimento habitual extramedular intradural relacionado com as raízes nervosas. O schwannoma melanocítico é uma variante dessas neoplasias cuja localização em quase um terço dos casos está na raiz nervosa posterior, com apresentação clínica inespecífica. A ressonância magnética é o exame de imagem mais utilizado no diagnóstico, revelando imagens hiperintensas em T1 e hipointensas em T2. A confirmação diagnóstica é obtida através do estudo histológico e imuno-histoquímico, em que se observa intensa pigmentação citoplasmática. Existem dois tipos distintos de schwannomas melanocíticos: o esporádico e o psamomatoso, este último relacionado ao chamado complexo de Carney, uma forma de neoplasia endócrina múltipla de caráter familiar. Na literatura, encontramos poucos casos dessas neoplasias, sendo a maior série composta por cinco casos. Assim, o objetivo deste trabalho é relatar um raro caso de schwannoma melanocítico da coluna lombar do tipo esporádico de localização extramedular. Apresentamos ainda uma breve revisão de literatura contendo as principais características do tumor, incluindo suas diferentes formas, diagnósticos diferenciais, dados do estudo histológico e imuno-histoquímico, bem como a abordagem atualmente preconizada, a fim de colaborar para o melhor entendimento desta neoplasia.
\end{abstract}

Descritores: Coluna vertebral; Neoplasias da coluna vertebral; Células de Schwann; Manipulação da coluna.

\section{RESUMEN}

Los schwannomas son tumores benignos, generalmente solitarios, encapsulados y de crecimiento lento, que tienen su origen en las células de Schwann neoplásicas diferenciadas con desarrollo habitual intradural extramedular relacionado con las raíces nerviosas. El schwannoma melanótico es una variante de estos tumores cuya localización en casi un tercio de los casos se encuentra en la raíz nerviosa posterior, con presentación clínica no específica. La resonancia magnética es el examen más ampliamente utilizado en el diagnóstico, con hiperintensidad en secuencias T1 e hiposeñal en T2. La confirmación del diagnóstico se obtiene por el estudio histológico e inmunohistoquímico, en el que existe una intensa pigmentación citoplásmica. Hay dos tipos distintos de schwannoma melanótico: el esporádico y el psamomatoso, este último relacionado con el llamado complejo de Carney, una forma de neoplasia endocrina múltiple de carácter familiar. En la literatura encontramos pocos casos de estos tumores, la serie más grande consta de cinco casos. El objetivo de este trabajo es presentar un caso raro de schwannoma melanótico lumbar del tipo esporádico y de localización extramedular. También presentamos una breve revisión de la literatura que contiene las principales características del tumor, incluyendo sus diferentes formas, los diagnósticos diferenciales, los datos del estudio histológico e inmunohistoquímico, así como el tratamiento recomendado actualmente, a fin de contribuir a una mejor comprensión de esta neoplasia.

Descriptores: Columna vertebral; Neoplasias de la columna vertebral; Células de Schwann; Manipulación espinal.

1. Escola Superior de Ciências da Santa Casa de Misericórdia de Vitória (EMESCAM), Vitória, ES, Brazil.

2. Hospital Santa Casa de Misericórdia de Vitória (HSCMV), Vitória, ES, Brazil.

Work developed at the Orthopedics andTraumatology Sector, Hospital Santa Casa de Misericórdia de Vitória (HSCMV), Vitória, ES, Brazil.

Correspondence: Rodrigo Rezende. Av. Desembargador Augusto Botelho, 209/801, Praia da Costa. 29.101-110 Vila Velha, ES, Brazil. rezenderodrigo@ hotmail.com 


\section{INTRODUCTION}

Schwannomas are benign, usually solitary, encapsulated and slow growth tumors originated from differentiated neoplastic Schwann cells, representing approximately $30 \%$ of primary tumors of the spine, normally developing extramedullary and intradural related to nerve roots. ${ }^{1}$

The melanocytic schwannoma is a variant of these neoplasms that occurs at younger ages compared to other schwannomas, being located in almost one third of cases in the posterior nerve root, ${ }^{2,3}$ although it can also be found in soft tissue, heart, orbit, oral cavity, stomach, bronchi, retroperitoneum, cervix and parotid. ${ }^{1,2}$ It has nonspecific clinical presentation, with secondary pain and root compression and dysesthesias, besides progressive motor and sensory deficits. ${ }^{2,3}$

Magnetic resonance imaging (MRI) is the most commonly used image diagnosis test, revealing hyperintense T1 and hypointense T2 images, whereas in schwannomas of the non-melanocytic type, the immage pattern is the opposite..$^{2-4}$

In the literature, we found few cases of melanocytic type schwannoma in the spine, the largest series consists of five cases. ${ }^{2}$ Thus, based on its extreme rarity, this paper aims to report a case of melanocytic schwannoma of the lumbar spine and conduce a brief literature review.

\section{CASE REPORT}

Male patient, 37 years old, without previous comorbidities, was referred to the Spinal Surgery Department of Hospital Santa Casa de Misericordia de Vitoria (HSCMV), ES, Brazil, with severe pain in the upper lumbar spine started two months before, radiating to the right anterolateral thigh, with radicular pattern in L1 and $\mathrm{L} 2$.

This study was approved by the Ethics Research Committee of EMESCAM with Presentation Certificate for Ethics Assessment number 19485813.0.0000.5065

The anteroposterior radiographs of the spine showed deletion of $\mathrm{L} 1$ pedicle to the right. During diagnostic testing by computed tomography (CT) and MRI of the lumbar spine, a voluminous expansive injury of aggressive nature was revealed, with spontaneously hyperintense signal on T1, heterogeneously low in T2, occupying the right half of the vertebral body of $L 1$, as well as its rear arc, breaking its lateral cortex, creeping into the neural L1-L2 right foramen, with an intracanalar component in "dumbbell" shape and showing no cleavage plane with the ipsilateral psoas. The injury measured $7.8 \times 4.2 \times 2.6 \mathrm{~cm}$ (LxTXAP) determining extension of corresponding neural foramen and compressive effect with reduced amplitude of the spinal canal. (Figure 1)

A surgical posterior approach was held, with resection of the posterior vertebral elements and release of the vertebra and iliopsoas muscle bilaterally, followed by instrumentation two levels above and two below the injury site. Material collected for histopathological study revealed fusiform morphology with intense cytoplasmic pigmentation, suggestive of metastatic melanoma. The immunohistochemical examination, however, revealed cytoplasmic and nuclear expression of S100 protein, vimentin, HMB-45, Ki-67 and SP6. This
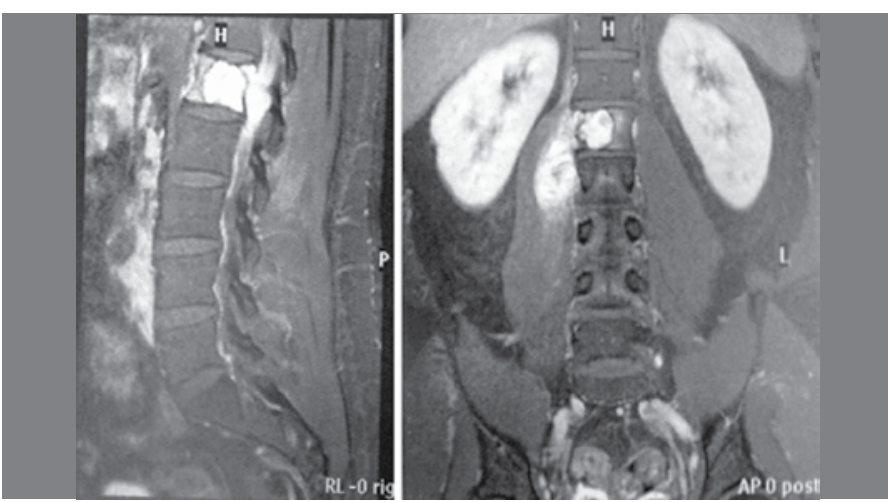

Figure 1. Magnetic resonance imaging in sagittal (left) and coronal cuts (right) in T1: hyperintense injury destroying L1 vertebral body, compressing the spinal canal and infiltrating right psoas muscle. lead to the conclusion, based on the findings and morphological characteristics of the injury, that it was a melanocytic non psammomatous schwannoma. (Figure 2)

The patient recovered well postoperatively, returning to walk the next day. Fifteen days later the patient was re-operated, this time by anterior approach with retro peritoneal access to $L 1$, and the tumor invading the right iliopsoas muscle was seen, encapsulating the ipsilateral genitofemoral nerve. The chosen procedure was a complete block resection of the tumor with the anterior body of L1 and the muscle in which it was infiltered, associated to anterior arthrodesis with autologous iliac graft. (Figures 3 and 4)

Chest drainage and placement of a suctor drain were performed. The patient evolved in the immediate postoperative period with $\mathrm{L} 2$ root neuropraxia, recovering after a month with physical therapy.

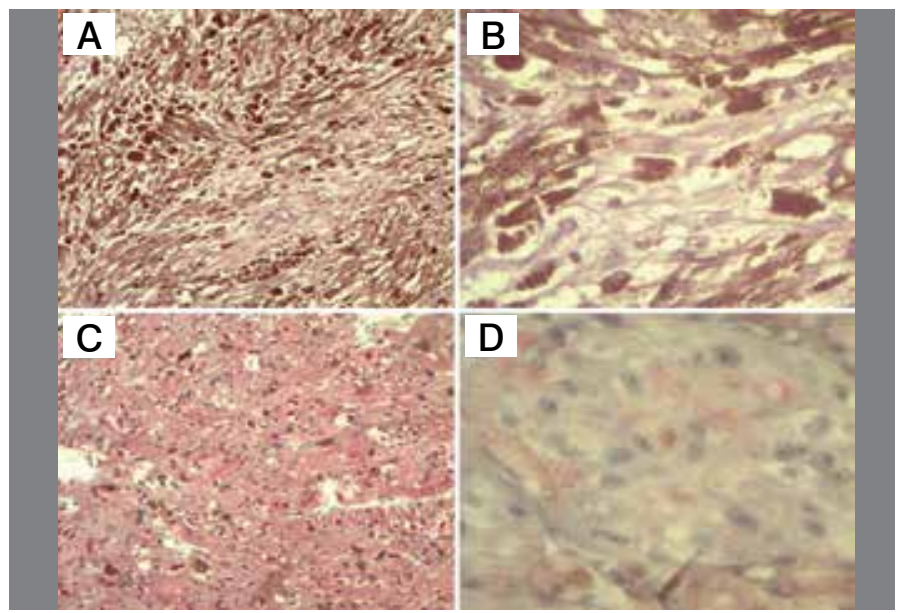

Figure 2. Histopathologic study (A) (x20) and (B) (x40): fusiform morphology with intense cytoplasmic pigmentation. Immunohistochemical study showing positivity for S100 protein (C) - x20 and vimentin (D) - x40.
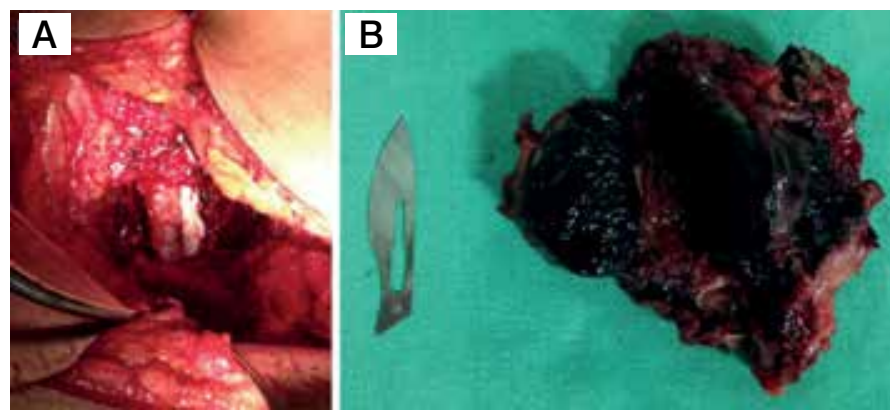

Figure 3. (A): Final appearance of intraoperative site: anterior lumbar arthrodesis with autologous iliac graft. (B): Surgical specimen: en bloc tumor resection.
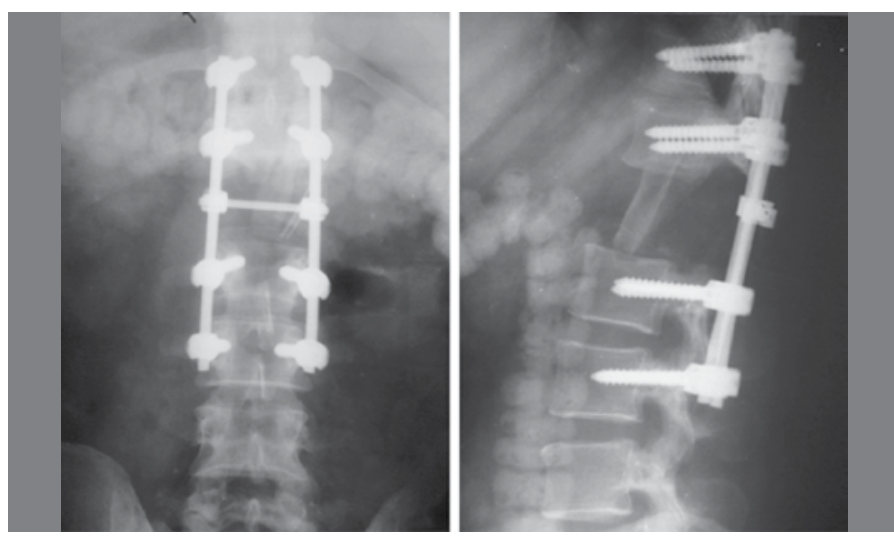

Figure 4. PA radiograph (left) and profile radiograph (right) of the lumbar spine showing the lumbar arthrodesis with autologous iliac graft. 


\section{DISCUSSION}

Detailed results of the literature review, including gender and age of patients, location and level of injury, as well as the treatment adopted and the follow up of cases are illustrated in Tables 1 and 2.1-8

We found a mean age of about 50 years old, the masculine gender being present in slightly more than half of the cases reviewed. The thoracic level was the most affected, with prevalence of extramedullary location (eight of the eleven reported cases), as well as in our patient, in which we found the development of extramedullary and intradural injury. Regarding treatment, partial resection was adopted in only one of the reports, in which the patient died in the immediate postoperative. In two cases there was local recurrence of the tumor after two years of follow-up, with reports of no reccurence in four cases, although the follow-up period was considered short, of slightly less than two years on average (between 10 months and 4 years).

There are two distinct types of melanocytic schwannomas: sporadic or non psammomatous and melanocytic psammomatous, the

Table 1. Literature review on reported cases of melanocytic schwannoma regarding year of publication, author, age and gender of patients, level and location of spinal injury*

\begin{tabular}{|c|c|c|c|c|c|}
\hline Year & Author & Age (years old) & Gender** & Level & Location* \\
\hline 1979 & Paris et al. ${ }^{5}$ & 49 & $\mathrm{~F}$ & Cervical & Extra \\
\hline 2004 & Santaguida et al..$^{1}$ & 35 & M & Cervical & Intra \\
\hline 2005 & Tawk et al. ${ }^{6}$ & 61 & $\mathrm{M}$ & Thoracic & Extra \\
\hline 2006 & De Cerchio et al. ${ }^{3}$ & 53 & $\mathrm{M}$ & Thoracic & Extra \\
\hline 2008 & Mouchaty et al. ${ }^{7}$ & 56 & $\mathrm{~F}$ & Thoracolumbar & Intra \\
\hline \multirow{2}{*}{2011} & \multirow{2}{*}{ Shields et al. ${ }^{8}$} & 65 & $\mathrm{~F}$ & Thoracic & Extra \\
\hline & & 33 & $\mathrm{M}$ & Lumbosacral & Extra \\
\hline 2012 & Welling et al. ${ }^{2}$ & $\begin{array}{c}50 \\
\text { (three cases) }^{* * *} \\
\end{array}$ & $2 \mathrm{M} / 1 \mathrm{~F}$ & $\mathrm{~N} / \mathrm{I}^{* * * *}$ & Extra \\
\hline 2012 & Hoover et al. ${ }^{4}$ & 62 & $\mathrm{~F}$ & Thoracic & Intra \\
\hline
\end{tabular}

${ }^{*}$ Regarding the spine - Extra: extramedullary. Intra: intramedullary. ${ }^{* *}$ M: masculine. F: feminine. ${ }^{* * *}$ Mean age among cases. ${ }^{* * *}$ Not informed.

Table 2. Literature review regarding resection characteristics and recurrence of injury.

\begin{tabular}{|c|c|c|c|}
\hline Year & Author & Resection & Tumor recurrence \\
\hline 1979 & Paris et al. ${ }^{5}$ & Complete & Absent after 4 years \\
\hline 2004 & Santaguida et al..$^{1}$ & Complete & Recurrence after 2 years \\
\hline 2005 & Tawk et al. ${ }^{6}$ & Complete & $\mathrm{N} / \mathrm{I}^{*}$ \\
\hline 2006 & De Cerchio et al..$^{3}$ & Complete & Absent after 2 years \\
\hline 2008 & Mouchaty et al. ${ }^{7}$ & Complete & Absent after a year \\
\hline \multirow{2}{*}{2011} & \multirow{2}{*}{ Shields et al. ${ }^{8}$} & Partial & Death on postoperative \\
\hline & & Complete & Recurrence after 2 years \\
\hline 2012 & Welling et al. ${ }^{2}$ & $\mathrm{Nl} *$ & $\mathrm{NI} *$ \\
\hline 2012 & Hoover et al. ${ }^{4}$ & Complete & Absent after 10 months \\
\hline
\end{tabular}

\section{REFERENCES}

1. Santaguida C, Sabbagh AJ, Guiot MC, Del Maestro RF. Aggressive intramedullary melanotic schwannoma: case report. Neurosurgery. 2004;55(6):1430

2. Welling LC, Guirado VM, Tessari M, Felix AR, Zanellato C, Figueiredo EG, et al. Spinal melanotic schwannomas. Arq Neuropsiquiatr. 2012;70(2):156-7.

3. De Cerchio L, Contratti F, Fraioli MF. Dorsal dumb-bell melanotic schwannoma operated on by posterior and anterior approach: case report and a review of the literature. Eur Spine J. 2006;15(Suppl 5):664-9.

4. Hoover JM, Bledsoe JM, Giannini C, Krauss WE. Intramedullary melanotic schwannoma. Rare Tumors. 2012;4(1):e3.

5. Paris F, Cabanes J, Muñoz C, Tamarit L. Melanotic spinothoracic schwannoma. Thorax. 1979;34(2):243-6. latter related $50 \%$ of the time to the so-called Carney complex. ${ }^{1}$ It is a form of familial autosomal dominant multiple endocrine neoplasia, characterized by the presence of skin and mucosa pigment alteration, primary nodular pigmentary adrenocortical disease, cardiac and cutaneous myxomas, GH and prolactin producer pituitary adenomas, testicular cancer, adenoma or carcinoma of the thyroid, as well as ovarian cysts. ${ }^{1,9}$ Given the association of the disease with systemic manifestations, besides its hereditary nature, active investigation of patients and their families is of capital importance for the prevention of future events. ${ }^{8}$ In the reported case, the patient had no family history or even components of the Carney complex.

The main differential diagnosis of melanocytic schwannomas include malignant melanoma, meningioma and pigmented neurofibroma, rhabdomyosarcoma, clear cell sarcoma of soft tissue, melanocytic medulloblastoma, and ganglioneuroblastoma, among others. ${ }^{8}$

Initially, most patients receive a diagnosis of primary or metastatic malignant melanoma. ${ }^{10}$ Microscopically, melanocytic schwannomas are typically composed of cells with abundant intracytoplasmic melanin pigmentation, besides psammomatous bodies in cases of non sporadic injury. Immunohistochemical study reveals a coloring pattern typical of other nerve sheath tumors, strongly expressing S-100 protein, Leu-7 and vimentin, while GFAP, CK and EMA are negative. The positivity for HMB-45 and Melan-A is an unexpected finding, given that these antibodies are considered relatively specific for the diagnosis of malignant melanoma. ${ }^{10}$

Reports indicate that in $10 \%$ of cases melanocytic schwannomas are malignant tumors, ${ }^{1,4,7}$ suggesting that the presence of melanocytic Schwann cells could predispose to malignant transformation in some patients. Regarding their recurrence potential, we found in the literature rates ranging from $18.2 \%{ }^{6}$ to $24 \%,{ }^{7}$ being almost always related to incomplete resections. ${ }^{1-4,7}$ Moreover, studies have shown that among patients who were followed for more than five years, only slightly more than half were disease free at the end of follow-up, suggesting that long term monitoring is necessary to assess tumor recurrence and risk of metastasis. ${ }^{10}$

\section{FINAL CONSIDERATIONS}

The ideal surgical approach is still complete resection of the tumor without aggravating the neurological deficits, the success of the surgery depending on the degree of malignancy and the presence of bone and visceral metastases. ${ }^{8}$ The value of radiotherapy remains unclear, ${ }^{2}$ needing larger prospective studies with longer follow-up to better understand the natural history, prognosis and ways to approach the injury.

All authors declare no potential conflict of interest concerning this article.
6. Tawk RG, Tan D, Mechtler L, Fenstermaker RA. Melanotic schwannoma with drop metastases to the caudal spine and high expression of CD117 (c-kit). J Neurooncol. 2005;71(2):151-6.

7. Mouchaty H, Conti R, Buccoliero AM, Conti P. Intramedullary melanotic schwannoma of the conus medullaris: a case report. Spinal Cord. 2008;46(10):703-6.

8. Shields LB, Glassman SD, Raque GH, Shields CB. Malignant psammomatous melanotic schwannoma of the spine: a component of carney complex. Surg Neurol Int. 2011;2:136.

9. Almeida MQ, Villares MC, Mendonça BB. Carney complex: a case report and literature review. Arq Bras Endocrinol Metabol. 2004:48(4):544-54.

10. Zhang HY, Yang GH, Chen HJ, Wei B, Ke Q, Guo H, et al. Clinicopathological, immunohistochemical, and ultrastructural study of 13 cases of melanotic schwannoma. Chin Med J (Engl). 2005;118(17):1451-61. 